\title{
Generational Differences Of Personal Values Of Business Students
}

Don E. Giacomino, Marquette University, USA

Jill Brown, Oklahoma State University, USA

Michael D. Akers, Marquette University, USA

\begin{abstract}
This paper examines the values and value systems of business students from a private mid-western university using the Rokeach Value Survey and the Musser and Orke Typology of Personal Values. The findings of this study are compared with the results of studies in the latter part of the 1990's and early 2000 in order to provide some insights regarding generational differences. There is evidence of changes in several individual variables during the past decade. For example, the value with the greatest change is National Security. Students in 2010 place more importance on this value than did the students in 1998. We also see a change in value systems where students are more concerned with achieving social goals through competence than with achieving social goals for moral reasons. Implications for accounting educators and practitioners are offered.
\end{abstract}

Keywords: Ethics; Values; Value Systems; Gender

\section{INTRODUCTION}

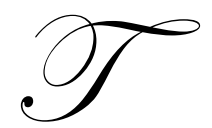

his study measures personal values and value types of business students. Researchers have defined values in several ways. Posner and Schmidt $(1987,341)$ define values as "general standards by which we formulate attitudes and beliefs and according to which we behave". Schwartz $(1992,2)$ defines values as "desirable goals varying in importance that serve as guiding principles in peoples' lives". Rokeach $(1973,16)$ sees values as "enduring beliefs that a specific mode of conduct or end-state of existence is personally or socially preferable to an opposite or converse mode of conduct or end-state of existence". Although several meanings of values exist, the common theme among those who have conducted research on values is that values influence behavior, and that is key to our study.

Burdett $(1998,27)$ suggests a link between personal values, corporate values and behavior. In exploring the twenty-first century organization, he indicates that "Employees with strong personal values aligned with the corporate culture work and behave (emphasis supplied) more effectively". Likewise, Finegan $(1994,747)$ shows that certain values predict perceptions and judgments about the morality of unethical behaviors. She also states that personal values can be influenced by corporate culture over time. Fritzsche $(1995,909)$ has also found some empirical evidence linking values to behaviors. Finally, Emde $(1998,83)$ holds that ethical practices result from employee personal values. He states that companies need to define and reconcile their corporate values to those individual employee personal values.

In the wake of numerous financial frauds during the most recent two decades, we have seen evidence of increasing interest in moral and ethical behavior in business. Most major corporations have adopted a code of conduct and have identified the values that are important to them (Benson, 1989, 305). The large accounting firms have also expressed an interest in ethical awareness (Ahadiat and Smith, 1994, 60). Coopers \& Lybrand (1997), for example, developed a Code of Business Conduct with four core values; Integrity, Teamwork, Mutual Respect and Personal Responsibility. PricewaterhouseCoopers LLP has a code of conduct with three key values; teamwork, excellence and leadership, along with a framework for ethical decision making (http://www.pwc.com/gx/en/ethicsbusiness-conduct/code-of-conduct.jhtml). Additionally, Statement on Auditing Standards (SAS) No. 109, applicable to audits beginning on or after December 15, 2006, requires auditors to perform procedures to gain an understanding 
of the client's integrity and ethical values. SAS No. 109 supersedes SAS No. 78 and SAS No. 55 which both dealt with consideration of internal control in a financial statement audit.

Values of university business majors are important to study because business majors represent the future leaders of organizations. In addition, research (Bruno and Lay, 2008, Connor and Becker, 2003, Fritzsche, 1995, Fritzsche and Oz, 2007, Finegan, 1994, and Karacaer et. Al, 2009) supports the premise that one's personal values influence behavior, including managerial and corporate strategy decisions. Because the personal values of these students will influence their behavior and determine the direction of businesses and other organizations in our society, it is useful to learn more about their values. Therefore, this study uses the Rokeach Values Survey (RVS) (1992) to better understand the personal values of university business majors.

This paper continues with an overview of the research on personal values in business. Following that overview, we describe the values measurement instruments, the Rokeach (1973) Values Survey, and the Musser and Orke (1992) model for classifying respondents by value type. Then, we describe our study, interpret the results, summarize, and discuss implications for future research on personal values.

\section{RESEARCH OVERVIEW}

Researchers began to focus on human values of business people and business students back in the 1970's. In 1973, Rokeach designed and used a survey instrument for measuring how individuals rank values. Two years later, England (1975) wrote about managers and their values in the U.S., Japan, Korea, India, and Australia. Baker (1976) followed with a study that investigated differences between the values of accounting and non-accounting majors. During the 80's, Swindle et. al. (1987) researched the values of CPA's.

Since the early 1990's, we have witnessed increased interest among researchers in personal values of business managers, business faculty, employees and students:

1. Fagenson (1993) studied the personal value systems of men and women entrepreneurs versus managers.

2. Singhapakdi and Vitell (1993) measured the personal and professional values underlying ethical judgments of marketers.

3. Finnegan (1994) studied the impact of personal values on judgments of ethical behavior in the workplace.

4. Fritzsche (1995) set the theoretical framework for identifying personal values as potential keys to ethical decision-making.

5. Sweeney (1995) explored the moral values of auditors.

6. Pinac-Ward et. al. (1995) examined personal values of university accounting professors.

7. $\quad$ Emde (1998) studied changing values of employees.

8. Cohen et. al. (1998) examined the effect of gender and academic discipline diversity on the ethical evaluation, ethical intentions and ethical orientation of potential public accounting results.

9. Giacomino and Akers (1998) examined the values of accounting and non-accounting majors.

10. Akers and Giacomino (1999) measured the personal values of certified internal auditors.

Research on ethics in the $21^{\text {st }}$ century began with studies by Akers and Giacomino (2000) and Eaton and Giacomino (2000 and 2001). Akers and Giacomino studied ethics and the accountant's code of conduct, and Eaton and Giacomino looked at differences in personal values of business students by gender (2000) and differences between the values of business managers and business students (2001). Giacomino and Akers (2000) measured the values and developed value profiles for the most influential people in accounting (100 most influential identified in Accounting Today and managing partners in the largest accounting firms) and compared them with values of business students, Japanese managers, and exemplary physicians. Also in 2000, Giacomino et. al. (2000) studied the effects of age and gender on values of Japanese executives. In 2003, Giacomino and Eaton measured the personal values of accounting alumni and tested for differences by age and gender.

Using four different instruments for measuring values, Hassan (2002) studied the personal value systems of accounting managers of CPA firms. Connor et. al. (2003) used the Rokeach Value Survey and the Rowe Decision Style inventory to find a relationship between managers' personal values and their decision-making styles. Both the 
Hassan and Connor studies found that personal values influenced the decision-making style. Using the Musser and Orke (1992) typology, Akers et. al. (2004) demonstrated how measuring the value types of students has the potential for changing students' values. Abdolmohammadi and Baker (2006) used the Rokeach Value Survey and the Defining Issues Test (DIT) (Rest: 1979) to survey 164 graduating accounting majors at two Northeastern universities. They found a highly significant relationship between "conformity" values and principled moral reasoning and that accounting students do not prefer conformity values above other values.

Baird and Zelin (2007) had 142 students complete the Schwartz (1992) Values Inventory and react to four ethical dilemma scenarios. Accounting majors were found to exhibit statistically higher disapproval of the unethical actions than the non-accounting majors for all four scenarios. Fritzsche and Oz (2007) used five types of ethical dilemmas to examine the relationship between personal values on the ethical dimension of decision-making and found a significant positive contribution of altruistic values to ethical decision-making. Lan et. al. (2008) used the Schwartz (1992) survey and the Defining Issues Test (Rest: 1979) and found that no statistically significant differences in levels of moral reasoning, rankings of values, and value types could be attributed to gender. However, they found that eight significant correlations between value types and levels of moral reasoning provide evidence that a systematic relationship exists. Boohene et. al. (2008) explored the impact of personal values on business owners' strategies for small businesses in Ghana. They found that gender differences in personal values lead to different strategies. Bruno et. al. (2008) surveyed 400 Brazilian executives and found a high positive relationship between personal values balance and leadership effectiveness.

Struwig (2008) found gender differences when she measured the values of business students in South Africa. Lan et. al. (2009) used the Schwartz (1992) survey to measure the personal values and value types of Chinese accounting practitioners (454) and graduate accounting students (126). They found that the male accounting practitioners and students rated the value type Achievement significantly higher than their female counterparts and there were several significant gender differences in personal values for practitioners and students.

Gibson et. al. (2009) looked for generational differences in personal values by surveying 5,057 members of Baby Boomers, Generation X and Generation Y. They found that the results confirm the popular profiles of the three generations. Karacaer et. al. (2009) distributed the Rokeach Values Survey and a case study to Pakistani and Turkish professional auditors to determine the effects of personal values on auditors' ethical decisions. They found no significant differences between the countries for moral intensity, but they found significant differences for terminal and instrumental values.

\section{THE ROKEACH VALUE SURVEY (RVS)}

One of the most popular instruments for measuring personal values is the Rokeach Value Survey (RVS). RVS is a classification system of values. Developed by social psychologist Milton Rokeach (1973), the system has two sets of values with 18 individual value items in each (See Table 1). One set is called terminal values the other instrumental values. RVS is based on a 1968 volume (Beliefs, Attitudes, and Values) which presented the philosophical basis for the association of fundamental values with beliefs and attitudes. Terminal Values refer to desirable end-states of existence. These are the goals that a person would like to achieve during his or her lifetime. These values vary among different groups of people in different cultures. Instrumental Values refer to preferable modes of behavior. Participants in the survey rank the 18 values in each set in order of importance to them, with 1 being most important and 18 being least important. Following is a classification of the values in the RVS: 
Table 1: Personal Values Survey

INSTRUCTIONS: Please rank the values in each of the two sets from 1 to 18

( 1 means most important and 18 means least important). As guiding principles in your life.

No ties please.

Set A Values

A Comfortable Life (Prosperous Life)

Equality (Brotherhood \& Equal Opportunity)

An Exciting Life (Stimulating, Active Life)

Family Security (Taking care of loved ones)

Freedom (Independence and free choice)

Health (Physical and mental well-being)

Inner Harmony (Freedom from inner conflict)

Mature Love (Sexual and spiritual intimacy)

National Security (Protection from attack)

Pleasure (An enjoyable, leisure life)

Salvation (Saved; eternal life)

Self-respect

A Sense of Accomplishment (lasting contribution)

Social Recognition (Respect and admiration)

True Friendship (Close companionship)

Wisdom (A mature understanding of Life)

A World at Peace (World free of war and conflict)

A World of Beauty (Beauty of nature and the arts)

AGE:

Gender: Female __ Male _

\begin{tabular}{|c|c|}
\hline Rank & $\underline{\text { Set B Values }}$ \\
\hline & Ambitious (Hardworking, As \\
\hline & Broad-minded (Open-minded \\
\hline & Capable (Competent; effectiv \\
\hline & Clean (Neat and tidy) \\
\hline & Courageous (Standing up for \\
\hline & Forgiving (Willing to pardon \\
\hline & Helpful (Working for the w \\
\hline & Honest (Sincere and truthfu \\
\hline & Imaginative (Daring and $\mathrm{cr}$ \\
\hline & Independent (Self-reliant; s€ \\
\hline & Intellectual (Intelligent and \\
\hline & Logical (Consistent; ratio \\
\hline & Loving (Affectionate and \\
\hline & Loyal (Faithful to friends \\
\hline & Obedient (Dutiful; respec \\
\hline & Polite (Courteous and well \\
\hline & Responsible (Dependable a \\
\hline & Self-controlled (Restrained \\
\hline \multicolumn{2}{|c|}{ MAJOR: $\mathrm{ACC}_{-} \mathrm{ECON}_{-} \mathrm{FIN}_{-} \mathrm{IT}_{-}$} \\
\hline \multicolumn{2}{|r|}{ Personal (self-focused) } \\
\hline \multicolumn{2}{|r|}{$\overline{\text { A Comfortable Life }}$} \\
\hline \multicolumn{2}{|r|}{ An Exciting Life } \\
\hline \multicolumn{2}{|r|}{ A Sense of Accomplishment } \\
\hline \multicolumn{2}{|r|}{ Health } \\
\hline \multicolumn{2}{|r|}{ Inner Harmony } \\
\hline \multicolumn{2}{|r|}{ Pleasure } \\
\hline \multicolumn{2}{|r|}{ Salvation } \\
\hline \multicolumn{2}{|r|}{ Self-respect } \\
\hline \multicolumn{2}{|r|}{ Wisdom } \\
\hline
\end{tabular}

\section{INSTRUMENTAL VALUES (behavioral)}

Moral (moral means to achieve goals)

Broadminded

Forgiving

Helpful

Honest

Loving

Loyal

Obedient

Polite

Responsible

Competence (focus on competence)
Ambitious
Capable
Clean
Courageous
Imaginative
Independent
Intellectual
Logical
Self-Controlled




\section{THE MUSSER AND ORKE TYPOLOGY OF PERSONAL VALUES}

Using the personal values survey instrument by Rokeach (1973), Musser and Orke (1992) developed a methodology for classifying people by value type. Musser and Orke indicate that people possessing the different value types described in the matrix (Table 2) behave quite differently, as follows:

- $\quad$ Virtuous Advocates (i.e., virtue leaders) are more concerned about helping the team reach its goals than about seeking their own personal goals. They also go about helping the team reach its goals by being sensitive to the needs and feelings of their associates. The trust and integrity resulting from this othercentered, other-sensitive focus helps associates to risk more and to become innovative. In a validation study, Musser and Orke identified Mother Teresa and Mahatma Gandhi as people who fit this value type.

- $\quad$ Independent Maximizers are more concerned about reaching their own goals than those of the team or organization. They also go about seeking to reach their personal goals in a detached, impersonal way that often ignores the needs and feelings of associates. Leaders with this type of value system are often viewed with a great deal of suspicion and mistrust. As a result, associates are unwilling to take risks and eventually become stagnant. According to the Musser and Orke validation study, Donald Trump and Ivan Boesky fit this value type.

- $\quad$ Honorable Egoists also seek to reach their own goals first, but they try to be sensitive to the needs and feelings of their associates in the process. Nevertheless, associates also tend to view these people with suspicion because of their focus on personal goals rather than team or organizational goals. They are not confident enough about their leader's motives to increase risk-taking and innovativeness. Arsenio Hall is a person who fits this value type, according to the Musser and Orke study.

- $\quad$ Effective Crusaders are more concerned about helping to reach the team's or organization's goals than about reaching their own personal goals. However, they often go about helping their associates reach team goals in a way that is insensitive and which ignores their needs and feelings. As a result, associates often find themselves in a love-hate relationship with these leaders. They want to love them because their heart is in the right place (reaching team goals), but their insensitive methods result in hurt and alienation. This, in turn, results in a reluctance to take chances and be more innovative. Oliver North fits this value type according to Musser and Orke.

The following summarizes each value system type and shows the associations between well-known individuals and the value system types.

Table 2: Value System Matrix: Results Then And Now

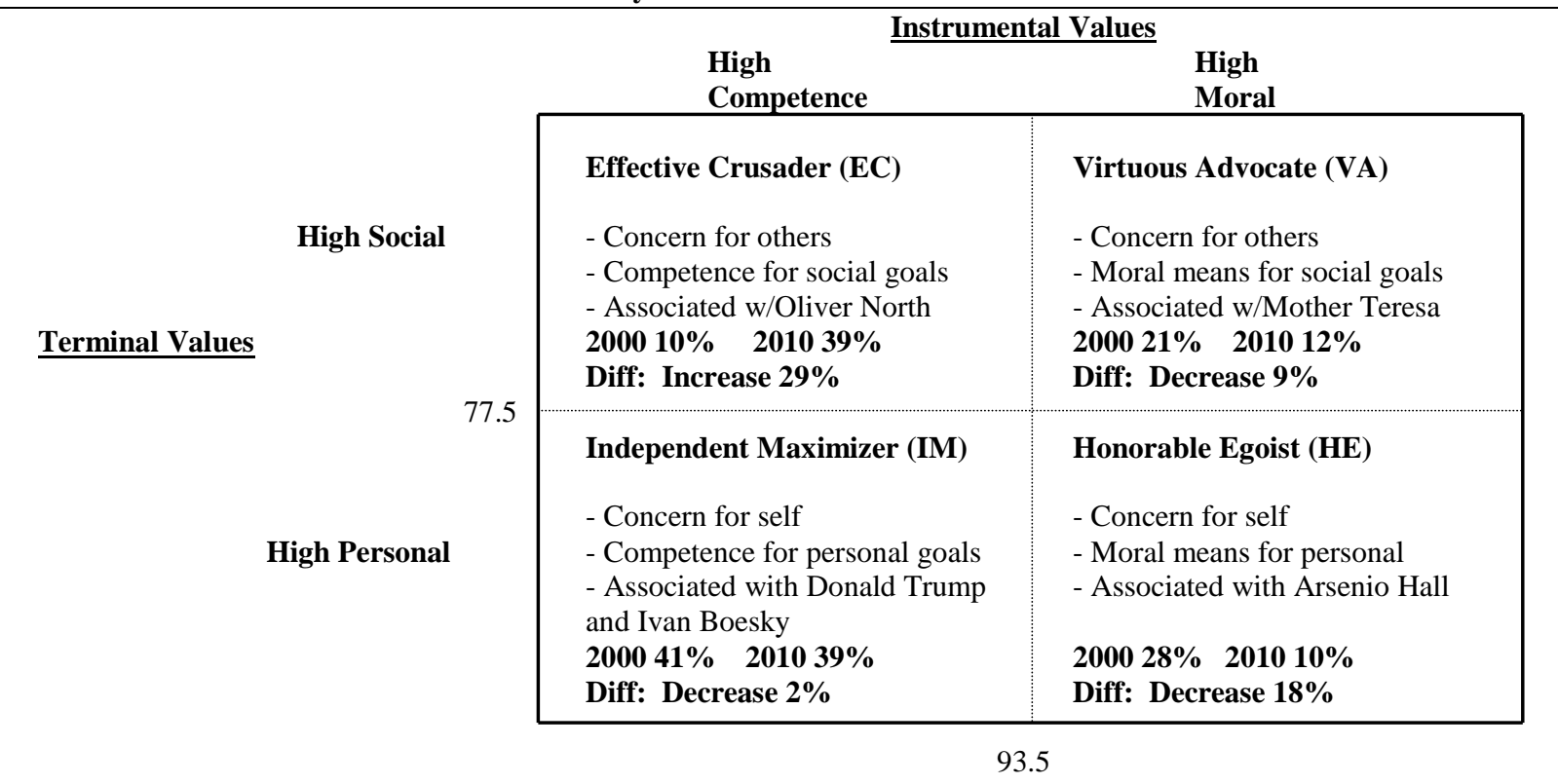


Summary of Value System Types

\begin{tabular}{llll} 
Value System Type & Reflects Concern For: & Emphasizes & Associated With \\
\hline Effective Crusader & Others & Competence to attain social goals & Oliver North \\
\hline Virtuous Advocate & Others & Moral means to attain social goals & $\begin{array}{l}\text { Mother Teresa } \\
\text { Mahatma Gandhi }\end{array}$ \\
\hline Independent Maximizer & Self & Competence to attain personal goals & $\begin{array}{l}\text { Donald Trump } \\
\text { Ivan Boesky }\end{array}$ \\
\hline Honorable Egoist & Self & Moral means to attain personal goals & Arsenio Hall \\
\hline
\end{tabular}

Musser and Orke found that these associations yielded good inter-rater reliability (Chi Square of 479.097, with $\mathrm{p}<.001)$. They conducted three separate studies to determine the usefulness of their typology. They established midlines for their Value System Matrix by using the mean coordinate scores for a sample of students from three different colleges. Given a subject's scores on the terminal and instrumental coordinates, they assigned the respondent to one of four types of value systems (or sets). As Musser and Orke state, "Although this scoring procedure treats ordinal data with interval-ratio procedures with differences in value preferences scaled equally, this need not be fatal to the analysis." Williams $(1968,287)$ points out that it is rare for a person's behavior to be guided only by one or two particular values. As situations vary, diverse clusters of values are called into play. To further validate their scoring procedure, Musser and Orke used SPSS Quick Cluster for a sample of 277 students. They observe that subjects falling into the same cluster quadrants do not necessarily display identical rank orderings of individual values. "The subject's classification is a product of his or her overall preference for the 'types' of Rokeach's values, not his or her preference for a specific value. The proposed typology allows a considerable degree of individuality within each value system type."

\section{OUR STUDY}

The Rokeach values survey was distributed to students in the Auditing as well as Financial Statement Analysis course at a private mid-western Jesuit institution. Students in the auditing course were all accounting majors, while the financial statement analysis course included both accounting and finance majors. Completion of the survey was anonymous and voluntary. Enrollment in the two courses was 93 students and 78 completed the survey, which yielded a response rate of $83.9 \%$. In order to examine generational changes for values and value systems, we compared our results with the findings of the Giacomino and Akers (1998) study and Eaton and Giacomino (2000) study.

\section{RESULTS}

\section{Values Survey}

The results of our survey are shown in the first column of Table 3. For comparative purposes between the generations, the results of the 1998 Giacomino and Akers study are also shown in Table 3. From 1998 to 2010, the order of instrumental values did not change dramatically apart from Logical, which increased in importance by seven spots. Several terminal values, however, were ranked much differently in 1998 than they were in 2010. The following shows those values which experienced an important increase or decrease of four spots or more.

Here, we will compare our results with those of some related studies and attempt to analyze the differences between 1998 and 2010. Greenwood et. al. (2008) used the Rokeach Value Survey to measure value differences between Baby Boomers, Generation X, and Generation Y. The business majors surveyed in the 1998 Giacomino and Akers study belong to Generation X, while those surveyed in our current study belong to Generation Y. The ranking of values in Greenwood et. al. (2008) for Generation X closely matches our results for Generation X with only a few differences. However, the results for Generation Y differ significantly between the two studies. This is expected for two reasons. First, Greenwood et. al. did not find many significant differences between terminal values for Generations $\mathrm{X}$ and $\mathrm{Y}$ in their study. Because values can differ significantly by generation, we expect to see more changes. Second, Greenwood et. al. used cross-sectional data in their study, meaning that members of Generation X 
and Generation Y were surveyed at different ages. Any differences or similarities in their study could possibly be attributed to age and stage of life, as well as to generation. Our study uses time-lagged data, meaning that at the time they were surveyed, students belonging to Generation X were the same age as those belonging to Generation $\mathrm{Y}$. Twenge et. al. (2010) prefer this methodology, as any changes between the generations must be due to the passage of time and generational differences, not age.

National Security, which was ranked 17th most important in 1998, saw the largest change. Students in 2010 ranked it as being 6th most important. A likely explanation for this is the fact that students in 2010 are living in a post-September 11, 2001 society and national security and terrorism are much more widely discussed than they were before the attack on the World Trade Center. National Security is more likely to be on students' minds now than it was in 1998.

Equality also increased in importance from 1998 to 2010, moving up eight spots on the list. Greenwood et. al. (2008) find that members of Generation Y desire to be treated equally with others in the workplace and often want promotions and responsibility more quickly than previous generations. Our results show this trend even more strongly.

The next largest increase was for Pleasure, which saw an increase in importance of seven spots. In the survey instrument used, Pleasure is equated to an enjoyable, leisurely life. Twenge et. al. (2010) do not use the Rokeach Value Survey, but they find that among work values (e.g. extrinsic and intrinsic rewards, the ability to socialize at work, etc.), Generation Y ranked Leisure as more important than did either Baby Boomers or Generation $\mathrm{X}$. In fact, in contrast to Generation $\mathrm{X}$, Leisure was the only work value that Generation $\mathrm{Y}$ ranked as more important; all other values were less important to $Y$ than they were to X. Twenge et. al. (2010) suggest that this is because Americans are working longer hours, so young employees are becoming more concerned with work/life balance and protecting their already limited leisure time.

Inner Harmony gained six spots between 1998 and 2010. Inner harmony, which is defined by the survey as freedom from inner conflict, may have increased due to Generation Y's desire for instant gratification and feedback. This generation may be more internally frustrated by uncertainty and not knowing where they stand in their relationships and careers. Greenwood et. al. (2009) find that members of Generation Y crave answers and feedback.

Social recognition increased in importance by four spots from 1998 to 2010 . When Generation X was surveyed in 1998, social networking sites were not as prevalent as they are now. With the popularity of social networking sites like Facebook, students in 2010 have a greater capability to have large social networks and an enhanced ability to control what information is revealed about them online. Students have more of a hands-on role in managing others' perceptions of themselves. These factors may have led students to focus more on how others view them. In addition, Twenge et. al. (2010) note that while Generation Y places Leisure above all other work values, this generation still craves status and recognition at work.

Freedom dropped eight spots in importance from 1998 to 2010. One possible explanation is that this drop is related to the increasing importance of National Security; students may be more willing to sacrifice freedoms to feel physically secure. Another explanation could be that students in 2010 feel secure in their Freedom, and do not rank it as being important because they have begun to take it for granted.

Mature Love also went down eight spots in importance between the two studies. One explanation could be that students in 2010 are more focused on finding a good job in a tough economy, so love and marriage rate lower in their priorities. It could also be that students in 2010 are more content to continue in their casual dating environment past college graduation. Jayson and DeBarros (2007) report that young people are choosing to marry later. While there is a general trend in this direction, they find that significant changes have taken place even in relatively short time periods. For example, they find that in 2006, 73 percent of men in their 20's reported never being married, which is an increase from 2000, when $64 \%$ had never been married. Because people are marrying later and later, marriage may simply not be on the minds of college students. 
Table 3: Rankings of Values (2010 vs. 1998)

Set A (TERMINAL)

Family Security

True Friendship

Pleasure

A Comfortable Life

Inner Harmony

National Security

Equality

Health

Self-respect

Social Recognition

A Sense of Accomplishment

Salvation

Wisdom

Freedom

Mature Love

An Exciting Life

A World at Peace

A World of Beauty

Set B (INSTRUMENTAL)

Honest

Ambitious

Responsible

Loyal

Intellectual

Courageous

Logical

Independent

Loving

Capable

Broad-minded

Self-controlled

Polite

Helpful

Forgiving

Obedient

Imaginative

Clean

Value

Pleasure

Inner Harmony

National Security

Equality

Health

Self-respect

Social Recognition

Freedom

Mature Love

An Exciting Life

Logical $\underline{2010}$

1

2

3

4

5

6

7

8

9

10

11

12

13

14

15

16

17

18

$\underline{2010}$

1

2

3

4

5

6

7

8

9

10

11

12

13

14

15

16

17

18

\section{$\underline{1998}$}

1

10

2

17

15

3

4

14

9

12

13

6

7

8

16

18

$\underline{1998}$

$\begin{array}{cc} & 1 \\ 3 & 3 \\ 4 & 2 \\ 5 & 4 \\ 6 & 7 \\ 7 & 8 \\ 8 & \mathbf{1 4} \\ 9 & 5 \\ 0 & 6 \\ 1 & 12 \\ 2 & 9 \\ 3 & 10 \\ 4 & 13 \\ 5 & 11 \\ 6 & 15 \\ 1 & 17 \\ 8 & 16 \\ & 18\end{array}$

$\begin{array}{ccc}\frac{\mathbf{2 0 1 0}}{3} & \mathbf{1 9 9 8} & \text { Increase }(+) \text { or Decrease }(-) \\ 5 & 10 & +7 \\ 6 & 11 & +6 \\ 7 & 17 & +11 \\ 8 & 15 & +8 \\ 9 & 3 & -5 \\ 10 & 4 & -5 \\ 14 & 14 & +4 \\ 15 & 6 & -8 \\ 16 & 7 & -8 \\ 14 & 8 & -8 \\ & 7 & +7\end{array}$


Students in 2010 ranked An Exciting Life eight spots lower than their counterparts did in 1998. This may be related to the 7-spot increase in Pleasure. In their discussion of the Leisure value, Twenge et. al. (2010) note that Americans work more than any other industrialized nation. Correspondingly, in their down-time, students may prefer to simply rest and relax, as opposed to seeking out thrills and excitement.

Health dropped five spots from 1998 to 2010. One possible explanation is that healthier lifestyles have been promoted in our culture. Students are becoming more health-conscious, and are therefore less worried about their health in the future. On the other hand, this drop could indicate that students simply care less about their health now than they did in 1998.

Finally, Self-Respect also dropped five spots from 1998 to 2010. This could be related to the decrease in the importance of intrinsic work rewards that Twenge et. al. (2010) note for Generation Y. Members of Generation $\mathrm{Y}$ care less about challenging themselves and finding meaning at work than previous generations. In their careers, people commonly find a degree of self-respect and pride over work completed, so a decline in valuing intrinsic work rewards corresponds to an overall decline in valuing Self-Respect.

\section{Musser-Orke Matrix}

For our study, we used the scoring procedure developed by Musser and Orke. The procedure is as follows:

1. For each set of values, terminal and instrumental (ends and means),we total the rankings of the following values in the terminal values group: Equality, Family Security, Freedom, Mature Love, National Security, Social Recognition, True Friendship, A World at Peace and A World of Beauty. These values comprise the social terminal values. The score for these values is determined by subtracting the total rankings from 171 (the sum of rankings for all values in the set). This method is equivalent to assigning the highest rated value a score of 18 and the lowest rated value a score of 1 . For example, if the sum of the rankings for the terminal were 87, then the score for the social terminal set of values would be 84 (171-87). Personal terminal values consist of the remaining terminal values. The score for the personal terminal values would be 87 . Thus, for these assumed rankings, the respondent's value set would be placed in the lower portion of the Value System Matrix depicted above.

2. To determine the score for instrumental value, we use the same procedure as for 1) above. The values included in the moral instrumental set are: Broadminded, Forgiving, Helpful, Honest, Loving, Loyal, Obedient, Polite and Responsible. The sum of the rankings for those values is then subtracted from 171 to get the moral competence score. If the respondents' rankings for these values were to total 72 , then the moral competence score would be 99 (171-72). This score would put the respondent in the right portion of the Value System Matrix.

3. Musser and Orke established and validated their cutoff scores (mean score) for terminal values as 77 and instrumental values as 93. Using their methodology, we established cutoff scores/lines in the Value System Matrix as 78.5 and 93.5. Therefore, using the assumed rankings from parts 1) and 2) above, the respondent ( 84 on the terminal axis and 99 on the instrument axis) would be classified in the Honorable Egoist (lower right) quadrant of the Value System Matrix.

We also found some significant changes in where students appeared in the Musser and Orke matrix. Table 2 shows the percentages for each category in both 2000 and 2010. The following summarizes the changes from 2000 to 2010. We see a shift toward the upper-left quadrant, the Effective Crusader (Table 2).

\begin{tabular}{lccc} 
& $\mathbf{2 0 0 0}$ & $\mathbf{2 0 1 0}$ & $\frac{\mathbf{\%} \text { Change }}{+20}$ \\
Social & 31 & 51 & -20 \\
Personal & 69 & 49 & +27 \\
Competence & 51 & 78 & -27 \\
Moral & 49 & 22 & \\
\hline
\end{tabular}


Between 1998 and 2010, we find an increase in students' preference for social terminal values and competence instrumental values. Today's students show more concern for others and social goals, but they may pursue these social goods without paying close attention to peoples' feelings or individual needs.

Many business schools place a strong emphasis on academics and professional success. These programs also often try to incorporate a sense of responsibility for society and others into the curriculum through service activities or discussions on ethics. These results suggest that students are listening and social goals are important to them, but they are pursuing social goals out of a sense of duty or a need to fulfill expectations, and not out of their own personal or moral conviction.

\section{LIMITATIONS}

This study has two inherent limitations. First, the sample was not randomly selected. All of student participants were enrolled in the researchers' classes. Secondly, all of the students attend a mid-western, faith-based, private university with an enrollment of approximately 12,000. Therefore, the sample may not be representative of all accounting and/or finance majors.

\section{CONTRIBUTIONS AND IMPLICATIONS}

This study provides two major contributions to the literature. First, this study updates the values literature by detailing how values have changed over time. Second, the findings of the study contribute to generational research by examining two different generations of business majors using a time-lagged study. Using a time-lagged study is especially important as it ensures that value changes are not the result of differences in age or stage of life.

An understanding of current student values (2010) is beneficial for educators as we continue to examine the relationship between values/value systems and ethical behavior in the classroom. Since the significant financial failures in the early 2000's, such as Enron and World Com, there is evidence of heightened awareness of ethics (i.e. ethical behavior) by academic institutions and accounting programs. The accounting profession has also placed a greater emphasis on ethics/integrity, as evidenced by the requirement of at least two hours of CPE devoted to ethics by most accounting professional certifications. An understanding of student values continues to be beneficial for the human resource department of accounting firms and accounting departments in determining whether the student's values are a good fit with the organization's values and for scheduling purposes. Our findings show that values of students can change over time, much like organizations change over time. An appropriate understanding of those changes is important to both academics and practitioners.

\section{FUTURE RESEARCH}

Future research on the values of business majors could be performed by comparing how business majors' values differ from those of accounting practitioners or students belonging to other majors. Twenge et. al. (2010) mention that narcissistic traits have increased from generation to generation, so further research could also examine whether this is true of business students and professionals.

\section{AUTHOR INFORMATION}

Dr. Don E. Giacomino, CPA is Professor of Accounting and the Donald and Beverly Flynn Chair Holder at Marquette University. He earned a DBA from the University of Kentucky and the MBA from the University of Montana. Giacomino has published a Management Accounting text and over 50 refereed articles in academic and professional journals, including Advances in Accounting, Journal of College Teaching and Learning, Journal of Accountancy, the CPA Journal, Issues in Accounting Education, International Business and Economics Research Journal and Journal of Managerial Issues. E-mail: don.giacomino@ marquette.edu 
Jill Brown, MSA is an accounting doctoral student at Oklahoma State University. She earned both her B.S. and M.S. in Accounting from Marquette University. During her time at Marquette, she served as the Wisconsin Institute of Certified Public Accountants' College Ambassador, was an officer in Marquette's chapter of Beta Alpha Psi, and interned with PricewaterhouseCoopers. E-mail: jill.brown@okstate.edu

Dr. Michael D. Akers, CPA, CIA, CMA, CFE, CBM is the Charles T. Horngren Professor of Accounting and Chair, Department of Accounting. He earned his doctoral degree at the University of Mississippi and his MBA at the University of Louisville. In addition to serving on the editorial advisory board of two journals, he has authored more than 50 articles in academic and professional journals. He currently serves on the Audit Committee and Board of Directors of two publicly traded companies and one not-for profit. E-mail: michael.akers@ marquette.edu

\section{REFERENCES}

1. Abdolmohammadi, M. J., and C. R. Baker. 2006. "Accountants' Value Preferences and Moral Reasoning" Journal of Business Ethics. Nov. 2006. Vol. 69, Issue 1: 11.

2. Ahadiat, N and K. J. Smith. 1994. 'A Factor-Analytic Investigation of Employee Selection Factors of Significance to Recruiters of Entry-level Accountants." Issues in Accounting Education. Vol. 9: 59-79

3. Akers, M.D. and D.E. Giacomino. 2000. "Ethics and The Accountant's Code of Conduct". The Journal of Applied Business Research. Vol. 7:87-95.

4. Akers, M.D. and D.E. Giacomino. 1999. "Personal Values of Certified Internal Auditors". Internal Auditing. (January/February): 19-27.

5. Akers, M. D., T. V. Eaton and D. E. Giacomino. 2004. "Monitoring and Changing the Values of Accounting Students". Journal of College Teaching and Learning, April 2004, Vol. 1: Nr. 4, 63-70.

6. Baird, J. E. and R. C. Zelin. 2007. "Personal Values and Ethical Viewpoints of Accounting Majors: How Do They Compare to Other Students?' Journal of Legal, Ethical and Regulatory Issues. Vol. 10, Iss. 2: 3955.

7. Baker, C. R. 1976. "An Investigation of Differences in Values: Accounting Majors vs. Non-accounting Majors." The Accounting Review. LI-4: 886-893.

8. $\quad$ Benson, G. 1989. "Code of Ethics.” Journal of Business Ethics. Vold. 8: 305-319

9. Boohene, R., A. Sheridan, and B. Kotey. 2008. 'Gender, Personal Values, Strategies and Small Business Performance: A Ghanian Case Study”. Equal Opportunities International. Vol. 27, Iss. 3: 237.

10. $\quad$ Bruno, L. and E. Lay. 2008. "Personal Values and leadership Effectiveness.” Vol. 61, Iss. 6: 678.

11. Burdett, J. D. 1998. "Beyond Values: Exploring the Twenty-First Century Organization." Journal of Management Development. Vol. 17: 27

12. Cohen, J. L. Pant and D. Sharp. 1998. "The Effect of Gender and Academic Discipline Diversity on the Ethical Evaluations, Ethical Intentions and Ethical Orientation of Potential Public Accounting Recruits.” Accounting Horizons V12: 250-270.

13. Connor, P. E. and B. W. Becker. 2003. "Personal Value Systems and Decision-Making Styles of Public Managers.” Public Personnel Management. Vol. 32, Iss. 1: 155-181.

14. Coopers \& Lybrand. 1997. The Way We Do Business: Our Code of Business Conduct. United States.

15. Eaton, T.V. and D.E. Giacomino. 2000. "Personal Values of Business Students: Differences by Gender and Discipline." Research on Accounting Ethics V. 7: 83-102.

16. _ 2001. "An Examination of Personal Values: Differences Between Accounting

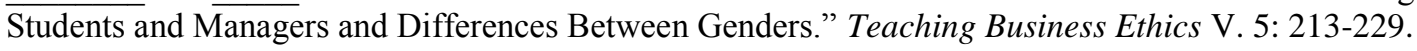

17. $\quad$ Emde, E. 1998. "Employee Values are Changing Course." Workforce V.77: 451-463.

18. England, G. W. 1975. The Manager and His Values: An International Perspective from the United States, Japan, Korea, India, and Australia. Cambridge, MA 5-67.

19. Fagenson, E. A. 1993. "Personal Value Systems of Men and Women Entrepreneurs versus Managers." Journal of Business Venturing 8: 409-430.

20. Finegan, J. 1994. "The Impact of Personal Values on Judgments of Ethical Behavior in the Workplace." Journal of Business Ethics 13: 747-755.

21. Fritzsche, D. J. 1995. "Personal Values: Potential Keys to Ethical Decision-Making." Journal of Business Ethics. Vol. 14: 909-923. 
22. Fritzsche, D. and E. Oz. 2007. "Personal Values' Influence on the Ethical Dimension of Decision Making." Journal of Business Ethics. Vol. 75, Iss. 4 : 335-344.

23. Giacomino, D. E. and M. D. Akers. 1998. "An Examination of the Differences between Personal Values and Value Types of Female and Male Accounting and Nonaccounting Majors." Issues In Accounting Education. Vol. 13. Nr. 3: 565-584

24. Giacomino, D. E., A. Fujita and T. M. Johnson. 2000. "Are the Effects of Age and Gender Changing the Personal Values Japanese Executives?” Business Forum. Vol. 24. Nrs 1,2: 15-21.

25. Giacomino, D. E. and T. V. Eaton. 2003. "Personal Values of Accounting Alumni: An Empirical Examination of Differences by Gender and Age". Journal of Managerial Issues, Vol. XV. Nr. 3: 369-380

26. Giacomino, D. E. and M. D. Akers. 2000. "Personal Values Profiles and Value Types of the Most Influential People in Accounting." Research on Accounting Ethics. Vol. 7: 141-156.

27. Gibson, J. W., R. A. Greenwood and E. F. Murphy Jr. 2009. "Generational Differences in the Workplace: Personal Values, Behaviors, and Popular Beliefs." Journal of Diversity Management. Vol. 4, Iss. 3: 1-8.

28. Greenwood, R. A., J. W. Gibson, and E. F. Murphy, Jr. 2008. "An Investigation of Generational Values in the Workplace: Divergence, Convergence, and Implications for Leadership." International Leadership Journal. Vol. 1, No.1, 57-76.

29. Hassan, M. T. 2002. "An Empirical investigation into the Personal Value Systems of Accounting Managers of CPA Firms." Disseration, Louisiana Tech. University, 191 pages. AAT 3054082

30. Jayson, S. and A DeBarros. 2007. "Young Adults Delaying Marriage." USA Today. http://www.usatoday.com/news/nation/2007-09-12-census-marriage N.htm

31. Karacaer, S., R. Gohar, M. Aygun, C. Sayin. 2009. "Effects of Personal Values on Auditor's Ethical Decisions: A Comparison of Pakistani and Turkish Professional Auditors." Journal of Business Ethics. Vol. 88, Iss. 1: 53-65.

32. Lan, G., M. Gowing, S. McMahon, R. Rieger, N. King. 2008. "Study of the Relationship between Personal Values and Moral Reasoning of Undergraduate Business Students." Journal of Business Ethics. Vol. 28, Iss. 1-2: 121-140.

33. Lan, G., Z. Ma, J. Cao, and H. Zhang. 2009. "A Comparison of Personal Values of Chinese Accounting Practitioners and Students." Journal of Business Ethics. Vol. 88: 59-77.

34. Musser, Steven J. and Eric Orke. 1992. "Ethical Value Systems: A Typology." The Journal of Applied Behavioral Science 28(3): 348-362.

35. Pinac-Ward, S., D. Ward and T. Wilson. 1995. "University Accounting Professors: An Examination of Personal Values." Accounting Educators' Journal V. 7: 39-53.

36. Posner, B., and W. Schmidt. 1987. Managerial Values across Functions: A Source of Organizational Problems. Group and Organization Studies 12(4): 373-385.

37. Rest, J.R. 1994. "Background: Theory and Research," in J.R. Rest and D. Narvaez (Eds.), Moral Development in the Professions (Hillsdale, NJ: Erlbaum): 1-26.

38. Rokeach, M. 1973. The Nature of Human Values. New York, NY: Free Press.

39. Schwartz, S. H.. 1992. "Universals in the Content and Structure of Values: Theoretical Advances and Empirical Tests in 20 Countries." Advances in Experimental Social Psychology. Academic Press

40. Singhapakdi, A. and S. J. Vitell. 1993. "Personal and Professional Values Underlying the Ethical Judgments of Marketers." Journal of Business Ethics 12: 525-533.

41. Struwig, M. 2008. "Exploring the Value Profiles of Business Students of South Africa." The Business Review: Cambridge. Vol. 9, Iss. 2: 55-62.

42. Sweeney, J. 1995. "The Moral Expertise of Auditors: An Exploratory Analysis." Research on Accounting Ethics V.1: 213-234.

43. Swindle, B., L. Phelps and R. Broussard. 1987. "Professional Ethics and Values of Certified Public Accountants." The Woman CPA April: 3.

44. Twenge, J. M., S. M. Campbell, B. J. Hoffman, and C. E. Lance. 2010. "Generational Differences in Work Values: Leisure and Extrinsic Values Increasing, Social and Intrinsic Values Decreasing." Journal of Management. Vol. 36. No. 5, 1117-1142. 